\title{
Pyrrolidine dithiocarbamates of Pd(II)
}

\author{
Giuseppina Faraglia $^{\mathrm{a}, *}$, Sergio Sitran ${ }^{\mathrm{b}}$, Diego Montagner ${ }^{\mathrm{a}}$ \\ a Dipartimento di Scienze Chimiche, Universita di Padova, via Marzolo 1, 35131 Padova, Italy \\ ${ }^{\mathrm{b}}$ Istituto di Chimica Inorganica e delle Superfici, C.N.R., Area della Ricerca, corso Stati Uniti, 4, 35127, Padova, Italy
}

Received 20 June 2004; accepted 20 September 2004

Available online 7 February 2005

\begin{abstract}
The dithioester $\left(\mathrm{CH}_{2}\right)_{4} \mathrm{NCS}_{2} \mathrm{CH}_{3}$ (PyDTM, 1-pyrrolidinecarbodithioate methyl ester) has been prepared by reaction of the parent ammonium salt $\mathrm{NH}_{4} \mathrm{PyDT}\left(\mathrm{PyDT}=\left(\mathrm{CH}_{2}\right)_{4} \mathrm{NCS}_{2}^{-}\right)$with methyl iodide in water/ethanol. The reaction of PyDTM with PdCl 2 allowed to synthesize either $\left[\mathrm{PdCl}_{2}(\mathrm{PyDTM})\right]$, in which the ligand is chelated by both sulfur atoms, or $\left[\mathrm{PdCl}{ }_{2}(\mathrm{PyDTM})_{2}\right]$, in which the ligand acts as monodentate through the thiocarbonyl sulfur. Thermal degradation of $\left[\mathrm{PdCl}_{2}(\mathrm{PyDTM})\right]$ yielded the $[\mathrm{PdCl}(\mathrm{PyDT})]_{n}$ species as an intermediate, which, in the presence of donors as chloride ions or dimethyl sulfoxide (DMSO), gave the complexes $[\mathrm{PdCl}(\mathrm{PyDT})(\mathrm{DMSO})]$ and $\mathrm{NR}_{4}\left[\mathrm{PdCl}_{2}(\mathrm{PyDT})\right]$. Moreover, PyDTM was found to react with various $[\mathrm{PdCl}(\mathrm{dithio}-$ carbamato $]_{n}$ intermediates to form the mixed species [PdCl(dithiocarbamato)(PyDTM)], whose thermal degradation yielded the $[\mathrm{Pd}($ dithiocarbamato)(PyDT) $]$ complexes. The behaviour of the prepared compounds in either solution or solid phase has been described on the basis of IR and proton NMR spectra and thermogravimetric analysis (TG and DTA).
\end{abstract}

(C) 2004 Elsevier B.V. All rights reserved.

Keywords: Palladium(II); Dithioesters; Syntheses; NMR; Thermal degradation

\section{Introduction}

Our interest on platinum(II) and palladium(II) complexes with sulfur containing molecules depends on their detoxicant properties against heavy metal intoxication. Despite of the wide number of platinum complexes which have been tested for antitumor properties (about 3000 in the last 30 years [1]), cisplatin is so far the most effective antitumor drug, along with a few carboxylato analogues [2-4]. A recent study on sulfur-bonding chemoprotective agents suggested diethyldithiocarbamate as the most effective rescue agent in a S-donor series (thiourea, thiosulfate and glutathione) against cisplatin toxicity [5]. In order to modulate cisplatin activity and toxicity, a new strategy concerns the design of new molecules containing either $\mathrm{N}$ or $\mathrm{S}$ donors [6-8].

\footnotetext{
${ }^{*}$ Corresponding author. Fax: +390498275161.

E-mail address: giuseppina.faraglia@unipd.it (G. Faraglia).
}

Among them, the dithiocarbamato complexes $\left[\mathrm{M}\left(\mathrm{S}_{2} \mathrm{CNEt}_{2}\right)(\mathrm{L})\right] \mathrm{NO}_{3}\left(\mathrm{M}=\mathrm{Pd}\right.$ or Pt; $\mathrm{L}=2,2^{\prime}$-bipyridyl or 1,10 leukaemie-phenanthroline) showed antitumor activity against leukaemic cells [9]. In this line, we reported various platinum and palladium complexes with dithioesters and dithiocarbamates which were tested for in vitro cytostatic activity against KB tumor cells [1012]. Among them, platinum and palladium complexes with dithioesters containing the sarcosine moiety produced interesting results. The complexes $\left[\mathrm{MCl}_{2}-\right.$ $($ ESDTM $)] \quad\left(\mathrm{M}=\mathrm{Pd} \quad\right.$ or $\mathrm{Pt} ; \quad \mathrm{ESDTM}=\mathrm{EtO}_{2} \mathrm{CCH}_{2}-$ $\left.\left(\mathrm{CH}_{3}\right) \mathrm{NCS}_{2} \mathrm{Me}\right)$ were prepared as a source for the related polymeric dithiocarbamates of formula $[\mathrm{MCl}(\mathrm{ESDT})]_{n}[13,14]$. The latter species reacts with amines in organic media to form the $[\mathrm{MCl}(\mathrm{ESDT})$ (amine)] complexes, which were tested for in vitro cytostatic activity against human leukaemic HL-60 and HeLa cells, the most active compounds being the pyridine (Py) derivatives of formula [MCl(ESDT)(Py)] [15]. 
The complex [PtCl(ESDT)(Py)] showed cytotoxic efficacy, the ability to overcome cisplatin resistance and low nephrotoxicity in respect to cisplatin [16,17], whereas the palladium analoge causes severe damages in the kidney [18]. The dithiocarbamates examined (essentially ESDT, $\mathrm{Me}_{2} \mathrm{DT}$ or $\mathrm{Et}_{2} \mathrm{DT}$ ) do not present particular properties by themselves, apart from the general detoxicant ability, whereas pyrrolidine dithiocarbamate has been widely reported in the last three years owing to antioxidant, antiviral and antiinflammatory properties and metal transport in membranes [19-24]. We thought then, of interest to extend the study to such a particular dithiocarbamate.

As a first study, this paper reports the palladium complexes with the dithioester PyDTM and with the dithiocarbamate PyDT
PyDTM<smiles>CSC(=S)N1CCCC1</smiles><smiles>S=C(S)N1CCCC1</smiles>

PyDT $^{--}$ along with mixed dithioester/dithiocarbamato species containing either $\mathrm{Me}_{2} \mathrm{NCS}_{2} \mathrm{Me}$ (DMDTM) and DMDT or ESDTM and ESDT.

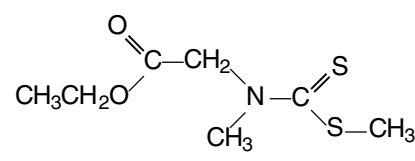

ESDTM

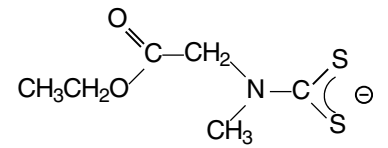

ESDT $^{--}$

\section{Experimental}

\subsection{Materials}

Palladium chloride, $\mathrm{NMe}_{4} \mathrm{Cl}, \mathrm{NBu}_{4} \mathrm{Cl}$ and $\left(\mathrm{CH}_{3}\right)_{2}$ $\mathrm{NCS}_{2} \mathrm{CH}_{2} \mathrm{C}_{6} \mathrm{H}_{5}$ (dimethyldithiocarbamate benzyl ester, DMDTB) were used as supplied (Aldrich products).

The dithioester PyDTM (1-pyrrolidinecarbodithioato methyl ester, $\left.\left(\mathrm{CH}_{2}\right)_{4} \mathrm{NCS}_{2} \mathrm{CH}_{3}\right)$ was prepared by reaction of an aqueous solution of $\mathrm{NH}_{4} \mathrm{PyDT}$ (ammonium 1-pyrrolidinecarbodithioate, Aldrich, $3.7 \cdot 10^{-2} \mathrm{~mol}$ in $\left.25 \mathrm{~cm}^{3}\right)$ with MeI $\left(3.5 \cdot 10^{-2} \mathrm{~mol}\right.$ in $10 \mathrm{~cm}^{3}$ of ethanol). The colorless warm solution separated on standing white crystals of the compound, which were filtered, washed with small fractions of $\mathrm{H}_{2} \mathrm{O} / \mathrm{EtOH}$ (1:1 vol./ vol.) and then with $\mathrm{H}_{2} \mathrm{O}$, and dried under reduced pressure. A further fraction of product was obtained by adding $\mathrm{H}_{2} \mathrm{O}$ to the mother solution. Yield: $95 \%$.

The dithioester ESDTM $\left[\mathrm{EtO}_{2} \mathrm{CCH}_{2}\left(\mathrm{CH}_{3}\right) \mathrm{NCS}_{2} \mathrm{Me}\right]$ was prepared by reaction of sarcosine ethyl ester with
$\mathrm{CS}_{2}$ and then with MeI [13], whereas DMDTM $\left(\mathrm{Me}_{2} \mathrm{NCS}_{2} \mathrm{Me}\right)$ was prepared by reaction of $\mathrm{Na}\left(\mathrm{Me}_{2}-\right.$ $\mathrm{CNS}_{2}$ ) with MeI [12].

The complex $[\mathrm{PdCl}(\mathrm{ESDT})]_{n}$ has been obtained by heating the parent $\left[\mathrm{PdCl}_{2}(\mathrm{ESDTM})\right]$ species on an oil bath $\left(120^{\circ} \mathrm{C}\right)$ under reduced pressure [25].

The complex $[\mathrm{PdCl}(\mathrm{DMDT})]_{n}$ was prepared by reaction of $\mathrm{PdCl}_{2}\left(5.1 \cdot 10^{-3} \mathrm{~mol}\right)$ with DMDTB $\left(5.2 \cdot 10^{-3}\right.$ mol in $15 \mathrm{~cm}^{3}$ of $\mathrm{CH}_{2} \mathrm{Cl}_{2}$ ). The suspension gradually transformed into a pink powder $(30 \mathrm{~h}$ with vigorous stirring), which was filtered from the orange solution, washed with $\mathrm{CH}_{2} \mathrm{Cl}_{2}$ and $n$-pentane and dried under reduced pressure. Yield: $88 \%$. If the reaction was carried out in benzene, mixtures of $[\mathrm{PdCl}(\mathrm{DMDT})]_{n}$ and $\left[\mathrm{PdCl}_{2}(\mathrm{DMDTB})\right]$ were obtained.

\subsection{Preparation of the complexes}

The complex $\left[\mathrm{PdCl}_{2}(\mathrm{PyDTM})\right]$ was prepared by adding PyDTM $(8.8 \mathrm{mmol})$ to a $\mathrm{PdCl}_{2}$ suspension in $\mathrm{CH}_{2} \mathrm{Cl}_{2}\left(8.0 \mathrm{mmol}\right.$ in $\left.10 \mathrm{~cm}^{3}\right)$ with vigorous stirring $(18 \mathrm{~h})$. The heterogeneous reaction yielded initially a brown solution, which gradually separated an orange solid. It was filtered, washed with $\mathrm{CH}_{2} \mathrm{Cl}_{2}$ and dried under reduced pressure. Yield: $90 \%$. Attempts to synthesize the compound in other solvents failed. In benzene, the reaction (at reagents molar ratio 1:1) was slow and unfinished within one week, whereas in acetone the product was always impure for the 1:2 adduct.

The complex $\left[\mathrm{PdCl}_{2}(\mathrm{PyDTM})_{2}\right]$ was prepared by reaction of $\mathrm{PdCl}_{2}\left(9.0 \cdot 10^{-4} \mathrm{~mol}\right)$ and PyDTM $\left(2.4 \cdot 10^{-3} \mathrm{~mol}\right)$ in $8 \mathrm{~cm}^{3}$ of $\mathrm{CH}_{2} \mathrm{Cl}_{2} /$ benzene $(1: 1 \mathrm{vol}$./ vol.). The brown solution separated ( $3 \mathrm{~h}$ under stirring) a brown solid, which was filtered, washed with benzene/ $n$-pentane (1:2 vol./vol.) and at the end with $n$-pentane fractions.

The polymeric species $[\mathrm{PdCl}(\mathrm{PyDT})]_{n}$ was obtained by heating under reduced pressure the parent [PdCl 2 (PyDTM)] complex up to $210{ }^{\circ} \mathrm{C}$ in an oil bath. The initially orange solid turns gradually to a pink solid, which is kept at $210^{\circ} \mathrm{C}$ per ca. $1 \mathrm{~h}$. The same product was obtained by heating up to $170{ }^{\circ} \mathrm{C}$ solid samples of [PdCl(PyDT)(DMSO)], obtained by stirring a $[\mathrm{PdCl}(\mathrm{PyDT})]_{n}$ suspension in a $\mathrm{CH}_{2} \mathrm{Cl}_{2} / n$-pentane $(1: 1$ vol./vol.) solution of dimethyl sulfoxide (DMSO, molar ratio 1:6, 1 d). The yellow solid was filtered, washed with $\mathrm{CH}_{2} \mathrm{Cl}_{2} / n$-pentane and dried under reduced pressure. Yield: $84 \%$.

The $\mathrm{NMe}_{4}\left[\mathrm{PdCl}_{2}(\mathrm{PyDT})\right]$ complex was obtained by adding $[\mathrm{PdCl}(\mathrm{PyDT})]_{n}\left(6.1 \cdot 10^{-4} \mathrm{~mol}\right)$ to a $\mathrm{NMe}_{4} \mathrm{Cl}$ solution in ethanol $\left(1.5 \cdot 10^{-3} \mathrm{~mol}\right.$ in $\left.5 \mathrm{~cm}^{3}\right)$. The orange solution separated, under stirring $(2 \mathrm{~h})$, an orange solid, which was filtered, washed with EtOH and $n$-pentane and dried under reduced pressure. Yield: $83 \%$. The $\mathrm{NBu}_{4}\left[\mathrm{PdCl}_{2}(\mathrm{PyDT})\right]$ analogue was obtained by dissolving $[\mathrm{PdCl}(\mathrm{PyDT})]_{n}\left(4.0 \cdot 10^{-4} \mathrm{~mol}\right)$ in a $\mathrm{CHCl}_{3}$ solution 
of $\mathrm{NBu}_{4} \mathrm{Cl}\left(4.4 \cdot 10^{-4} \mathrm{~mol}\right.$ in $\left.10 \mathrm{~cm}^{3}\right)$. Traces of unreacted dithiocarbamate were filtered away and the orange solution was treated with $\mathrm{Et}_{2} \mathrm{O}$. The red oily product was decanted from the orange solution and dried under reduced pressure. The oil solidified on standing ( $5 \mathrm{~d}$ ) yielding an orange solid, which was washed with $\mathrm{Et}_{2} \mathrm{O}$. Yield: $60 \%$.

The complex $[\mathrm{PdCl}(\mathrm{PyDT})(\mathrm{PyDTM})]$ was prepared by adding $[\mathrm{PdCl}(\mathrm{PyDT})]_{n}\left(5.0 \cdot 10^{-4} \mathrm{~mol}\right)$ to a PyDTM solution in benzene $\left(1.5 \cdot 10^{-3} \mathrm{~mol}\right.$ in $\left.5 \mathrm{~cm}^{3}\right)$ under stirring $(3 \mathrm{~d})$. The orange solid was filtered, washed with benzene/n-pentane $(1: 1$ vol./vol. $)$ and with $n$-pentane. Yield: $80 \%$. If $[\mathrm{PdCl}(\mathrm{PyDT})]_{n}$ was treated with a different dithioester in the same conditions, no appreciable reaction was observed. As an example, a suspension of $[\mathrm{PdCl}(\mathrm{PyDT})]_{n}$ in a benzene solution of ESDTM, at molar ratios from 1:1 to $1: 4$, did not show any change after a week under vigorous stirring, as for the [PdCl$(\text { PyDT }]_{n} /$ DMDTM system.

The species [PdCl(DMDT)(PyDTM)] and [PdCl(ESDT)(PyDTM)] were prepared by reaction of the parent $[\mathrm{PdCl} \text { (dithiocarbamato) }]_{n}$ intermediate with PyDTM in benzene (molar ratio 1:1.1, overnight with stirring). The orange powder was filtered, washed with benzene/ $n$-pentane (1:1 vol./vol.) and then with $n$-pentane. Yield: ca. $65 \%$.

The mixed bis-dithiocarbamate [Pd(DMDT)(PyDT)] was obtained by heating $[\mathrm{PdCl}(\mathrm{DMDT})(\mathrm{PyDTM})]$ in an oil bath $\left(160^{\circ} \mathrm{C}\right)$ under reduced pressure. The yellow compound has also been prepared by reaction of $[\mathrm{PdCl}(\mathrm{DMDT})]_{n} \quad\left(5.8 \cdot 10^{-4} \mathrm{~mol}\right)$ with $\mathrm{NH}_{4} \mathrm{PyDT}$ $\left(6.4 \cdot 10^{-4} \mathrm{~mol}\right)$ in EtOH with stirring $(6 \mathrm{~h})$. The powder was filtered, washed with EtOH and $n$-pentane and dried under reduced pressure. Accordingly, [Pd(ESDT)(PyDT)] was obtained either by thermal degradation of the parent $[\mathrm{PdCl}(\mathrm{ESDT})(\mathrm{PyDTM})]\left(160{ }^{\circ} \mathrm{C}\right)$ or by reaction of $[\mathrm{PdCl}(\mathrm{ESDT})]_{n}$ with $\mathrm{NH}_{4} \mathrm{PyDT}$ in ethanol (molar ratio $1: 1.3$ ).

The $\left[\mathrm{Pd}(\mathrm{PyDT})_{2}\right]$ complex was prepared by thermal degradation of solid samples of either $\left[\mathrm{PdCl}_{2}(\mathrm{PyDTM})_{2}\right]$ $\left(160^{\circ} \mathrm{C}\right)$ or $[\mathrm{PdCl}(\mathrm{PyDT})(\mathrm{PyDTM})]\left(170^{\circ} \mathrm{C}\right)$. Otherwise, it was prepared by reaction of $\mathrm{K}_{2}\left[\mathrm{PdCl}_{4}\right]$ and $\mathrm{NH}_{4} \mathrm{PyDT}$ in $\mathrm{H}_{2} \mathrm{O}$ (molar ratio 1:2), as for [Pd(DMDT) $\left.)_{2}\right]$. Samples of the yellow $\left[\mathrm{Pd}(\mathrm{ESDT})_{2}\right]$ compound were prepared by heating $\left[\mathrm{PdCl}_{2}(\mathrm{ESDTM})_{2}\right]$ on an oil bath $\left(140{ }^{\circ} \mathrm{C}, 2 \mathrm{~h}\right)$ in the air [13].

\subsection{Measurements}

Elemental analyses were carried out on a Fisons EA1108 CHNS-O microanalyser. IR spectra were recorded on Nicolet 5SXC FT-IR and 20F Far-IR spectrometers, as either Nujol mulls between $\mathrm{KBr}$ and polyethylene discs or as $\mathrm{KBr}$ pellets. NMR spectra were measured using a Bruker DRX 300 (ppm; internal standard, TMS). Thermogravimetric data in air were obtained on Netzsch STA 449 thermoanalytical equipment (flux rate, $50 \mathrm{~cm}^{3} \mathrm{~min}^{-1}$; heating rate, $5{ }^{\circ} \mathrm{C} \mathrm{min}{ }^{-1}$; and ref. material $\mathrm{Al}_{2} \mathrm{O}_{3}$ ). The weight of the samples in the crucible was about $15-25 \mathrm{mg}$.

\section{Results and discussion}

The ligand PyDTM was prepared by reaction of the salt $\mathrm{NH}_{4} \mathrm{PyDT}$ with methyl iodide in $\mathrm{H}_{2} \mathrm{O} / \mathrm{EtOH}$ (molar ratio 1:1; Table 1). The complex $\left[\mathrm{PdCl}_{2}(\mathrm{PyDTM})_{2}\right]$ was obtained by reaction of $\mathrm{PdCl}_{2}$ and ligand (molar ratio ca. 1:3) in $\mathrm{CH}_{2} \mathrm{Cl}_{2} /$ benzene. It is necessary to operate with a ligand excess, otherwise the samples of the brown product contain appreciable amounts of the orange 1:1 species. Impure samples were also isolated when the reaction was performed in dichloromethane, addition of benzene stabilizing the 1:2 complex, which is scarcely soluble in the mixed solvent medium. The complex $\left[\mathrm{PdCl}_{2}(\mathrm{PyDTM})\right]$ has been prepared by reaction of $\mathrm{PdCl}_{2}$ and PyDTM (molar ratio 1:1) in dichloromethane. The reaction trend suggests that the brown $\left[\mathrm{PdCl}_{2}(\mathrm{PyDTM})_{2}\right]$ solid is formed at first, which reacts slowly with the residual palladium salt yielding the orange 1:1 product. The suspension should be kept in the dark, otherwise either [PdCl(PyDT)(PyDTM)] or $[\mathrm{PdCl}(\mathrm{PyDT})]_{n}$ are formed as side products. Large amounts of side products were present by operating in acetone, whereas the reaction was slow in benzene, the resulting samples containing always unreacted palladium chloride.

As observed previously, the palladium dithioester adducts present a low thermal stability $[12,13]$. They undergo $S$-demethylation yielding the corresponding dithiocarbamates $[\mathrm{MCl}(\text { dithiocarbamato })]_{n}$ and $[\mathrm{M}$ $\left.(\text { dithiocarbamato })_{2}\right]($ dithiocarbamato $=$ ESDT, DMDT or DEDT) as degradation intermediates [13,25]. As shown in Fig. 1, degradation of $\left[\mathrm{PdCl}_{2}(\mathrm{PyDTM})\right]$ starts at $150{ }^{\circ} \mathrm{C}$ (Table 2), the first step (endotherm at $189^{\circ} \mathrm{C}$ ) corresponding to quantitative evolution of methyl chloride (weight loss of $14.8 \%$ against a calculated value of $14.9 \%)$. The $[\mathrm{PdCl}(\mathrm{PyDT})]_{n}$ intermediate is stable in the 200-280 ${ }^{\circ} \mathrm{C}$ temperature interval, the subsequent decomposition process ending at ca. $400{ }^{\circ} \mathrm{C}$ with formation of palladium (total weight loss, $67.4 \%$ against a calculated value of $68.6 \%$ ). The weight increase in the $510-780{ }^{\circ} \mathrm{C}$ temperature interval is caused by non-stoichiometric oxygen uptake on the sample surface to form $\mathrm{PdO}$, which releases oxygen at $823{ }^{\circ} \mathrm{C}$. Such a behaviour in the $400-850$ ${ }^{\circ} \mathrm{C}$ interval is common to all palladium complexes with either dithioesters or dithiocarbamates examined so far, whereas the platinum analogues decompose generally to platinum below $500{ }^{\circ} \mathrm{C}$, the metal showing no tendency to react with oxygen. Thermal decomposition of solid $\left[\mathrm{PdCl}_{2}(\mathrm{PyDTM})\right]$ allows to obtain the polymeric species $[\mathrm{PdCl}(\mathrm{PyDT})]_{n}$, which, being coordinatively unsaturated, 
Table 1

Analytical $^{\mathrm{a}}$ and physical data

\begin{tabular}{|c|c|c|c|c|c|c|c|}
\hline \multirow[t]{2}{*}{ Compound } & \multirow[t]{2}{*}{ Formula } & \multirow[t]{2}{*}{ Color } & \multirow[t]{2}{*}{$\mathrm{C}$} & \multirow[t]{2}{*}{$\mathrm{H}$} & \multirow[t]{2}{*}{$\mathrm{N}$} & \multicolumn{2}{|l|}{$v(\mathrm{CN})\left(\mathrm{cm}^{-1}\right)$} \\
\hline & & & & & & Dithioesther & Dithiocarbamato \\
\hline PyDTM & $\mathrm{C}_{6} \mathrm{H}_{11} \mathrm{NS}_{2}$ & white & $44.5(44.7)$ & $6.7(6.8)$ & $8.8(8.7)$ & 1464 & \\
\hline$\left[\mathrm{PdCl}_{2}(\mathrm{PyDTM})\right]$ & $\mathrm{C}_{6} \mathrm{H}_{11} \mathrm{Cl}_{2} \mathrm{NPdS}_{2}$ & orange & $21.4(21.3)$ & $3.0(3.3)$ & $3.9(4.1)$ & 1583 & \\
\hline$[\mathrm{PdCl}(\mathrm{PyDT})]_{n}$ & $\mathrm{C}_{5} \mathrm{H}_{8} \mathrm{ClNPdS}_{2}$ & pink & $20.9(20.8)$ & $2.6(2.8)$ & $4.7(4.8)$ & & 1548 \\
\hline$\left[\mathrm{PdCl}_{2}(\mathrm{PyDTM})_{2}\right]$ & $\mathrm{C}_{12} \mathrm{H}_{22} \mathrm{Cl}_{2} \mathrm{~N}_{2} \mathrm{PdS}_{4}$ & brown & $28.7(28.8)$ & $4.3(4.4)$ & $5.4(5.6)$ & 1495 & \\
\hline$\left[\mathrm{Pd}\left(\mathrm{PyDT}_{2}\right]\right.$ & $\mathrm{C}_{10} \mathrm{H}_{16} \mathrm{~N}_{2} \mathrm{PdS}_{4}$ & yellow & $29.8(30.1)$ & $3.8(4.0)$ & $6.7(7.0)$ & & 1511 \\
\hline $\mathrm{NMe}_{4}\left[\mathrm{PdCl}_{2}(\mathrm{PyDT})\right]$ & $\mathrm{C}_{9} \mathrm{H}_{20} \mathrm{Cl}_{2} \mathrm{~N}_{2} \mathrm{PdS}_{2}$ & orange & $27.6(27.2)$ & $4.7(5.0)$ & $7.0(7.0)$ & & 1533 \\
\hline $\mathrm{NBu}_{4}\left[\mathrm{PdCl}_{2}(\mathrm{PyDT})\right]$ & $\mathrm{C}_{21} \mathrm{H}_{44} \mathrm{Cl}_{2} \mathrm{~N}_{2} \mathrm{PdS}_{2}$ & orange & $45.0(44.6)$ & $8.8(7.8)$ & $5.0(4.9)$ & & 1525 \\
\hline$[\mathrm{PdCl}(\mathrm{PyDT})(\mathrm{PyDTM})]$ & $\mathrm{C}_{11} \mathrm{H}_{19} \mathrm{ClN}_{2} \mathrm{PdS}_{4}$ & orange & $29.6(29.4)$ & $3.6(4.3)$ & $5.8(6.2)$ & 1495 & 1523 \\
\hline$[\mathrm{PdCl}(\mathrm{DMDT})(\mathrm{PyDTM})]$ & $\mathrm{C}_{9} \mathrm{H}_{17} \mathrm{ClN}_{2} \mathrm{PdS}_{4}$ & orange & $25.4(25.5)$ & $3.9(4.0)$ & $7.0(6.6)$ & 1498 & 1561 \\
\hline$[\mathrm{PdCl}(\mathrm{ESDT})(\mathrm{PyDTM})]$ & $\mathrm{C}_{12} \mathrm{H}_{21} \mathrm{ClN}_{2} \mathrm{O}_{2} \mathrm{PdS}_{4}$ & red oil & $28.8(29.1)$ & $3.9(4.3)$ & $5.4(5.6)$ & 1508 & $1520^{\mathrm{b}}$ \\
\hline$[\mathrm{Pd}(\mathrm{DMDT})(\mathrm{PyDT})]$ & $\mathrm{C}_{8} \mathrm{H}_{14} \mathrm{~N}_{2} \mathrm{PdS}_{4}$ & yellow & $25.7(25.8)$ & $3.5(3.8)$ & $7.2(7.5)$ & & 1511,1548 \\
\hline$[\mathrm{Pd}(\mathrm{ESDT})(\mathrm{PyDT})]$ & $\mathrm{C}_{11} \mathrm{H}_{18} \mathrm{~N}_{2} \mathrm{O}_{2} \mathrm{PdS}_{4}$ & yellow & $29.3(29.7)$ & $3.8(4.1)$ & $6.1(6.3)$ & & $1514^{\mathrm{c}}$ \\
\hline$\left[\mathrm{Pd}(\mathrm{DMDT})_{2}\right]$ & $\mathrm{C}_{6} \mathrm{H}_{12} \mathrm{~N}_{2} \mathrm{PdS}_{4}$ & yellow & $21.1(20.8)$ & $3.5(3.5)$ & $8.2(8.1)$ & & 1548 \\
\hline$\left[\mathrm{Pd}(\mathrm{ESDT})_{2}\right]$ & $\mathrm{C}_{12} \mathrm{H}_{20} \mathrm{~N}_{2} \mathrm{O}_{4} \mathrm{PdS}_{4}$ & yellow & $29.1(29.4)$ & $4.1(4.1)$ & $5.7(5.7)$ & & $1517^{\mathrm{d}}$ \\
\hline$[\mathrm{PdCl}(\mathrm{PyDT})(\mathrm{DMSO})]$ & $\mathrm{C}_{7} \mathrm{H}_{14} \mathrm{ClNOPdS}_{3}$ & yellow & $22.8(23.0)$ & $3.7(3.8)$ & $3.7(3.8)$ & & 1554 \\
\hline
\end{tabular}

${ }^{\text {a }}$ Calculated values $(\%)$ in parentheses.

b $v(\mathrm{CO}), 1745 \mathrm{~cm}^{-1}$.

c $v(\mathrm{CO}), 1742 \mathrm{~cm}^{-1}$

d $v(\mathrm{CO}), 1739 \mathrm{~cm}^{-1}$.

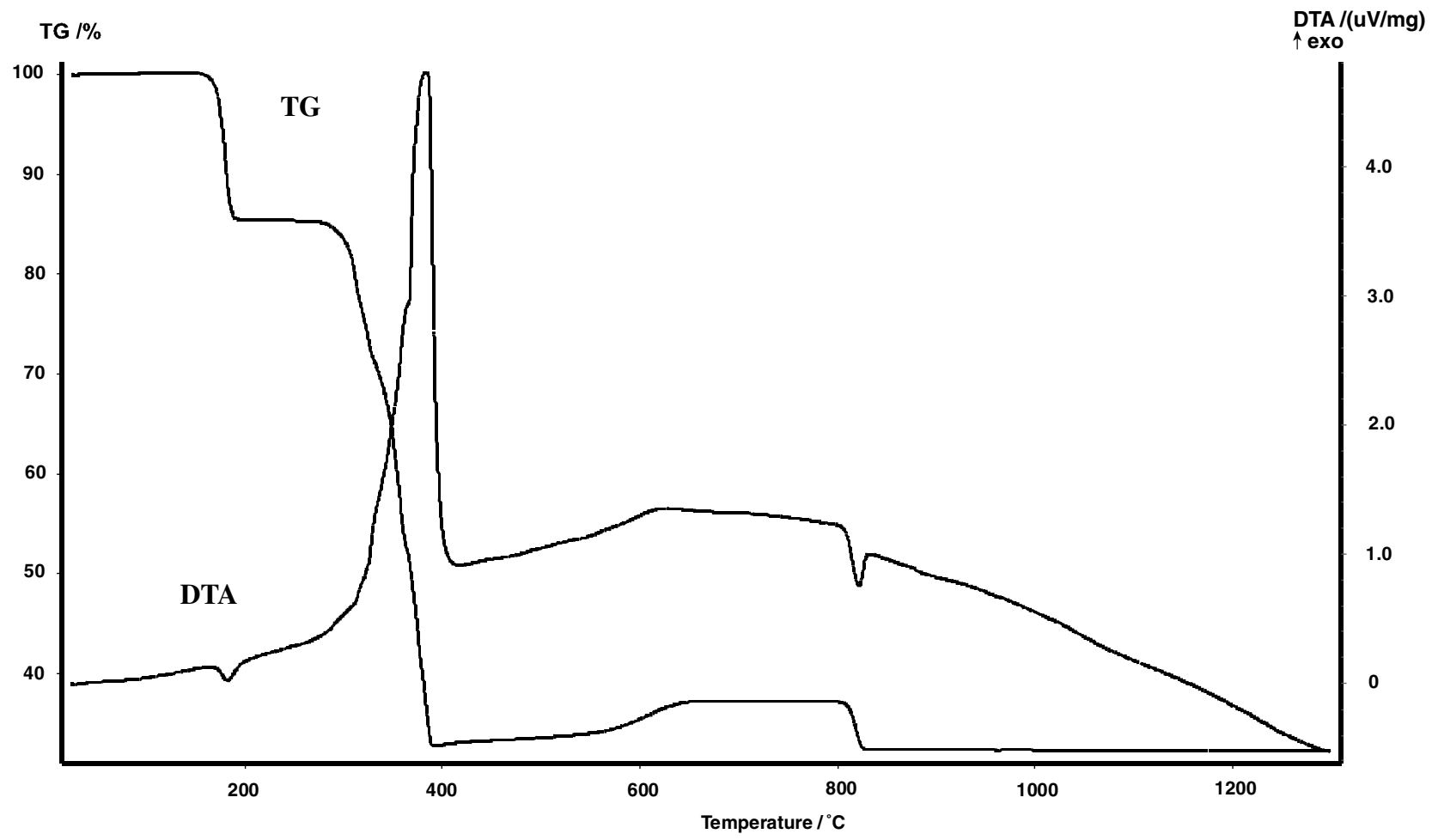

Fig. 1. Thermograms of $\left[\mathrm{PdCl}_{2}(\mathrm{PyDTM})\right]$.

can easily bind $\mathrm{N}, \mathrm{S}$ or $\mathrm{P}$ donors yielding a variety of mixed complexes. It is not possible to synthesize the polymeric intermediate by direct reaction of $\mathrm{K}_{2}\left[\mathrm{PdCl}_{4}\right]$ and PyDT anion. Attempts in water or in water/alcohol media at various stoichiometric ratios always separated the species $\left[\mathrm{Pd}(\mathrm{PyDT})_{2}\right]$, as observed previously for various dithiocarbamato ions. The complex $[\mathrm{PdCl}(\mathrm{PyDT})]_{n}$ is then obtained as a pink powder by gradually heating the orange $\left[\mathrm{PdCl}_{2}(\mathrm{PyDTM})\right]$ complex up to $210^{\circ} \mathrm{C}$, in oil bath under reduced pressure. The $\left[\mathrm{PdCl}_{2}(\mathrm{PyDTM})_{2}\right]$ complex is stable up to $130{ }^{\circ} \mathrm{C}$ (Fig. 2). In the $130-200{ }^{\circ} \mathrm{C}$ temperature interval two methyl chloride molecules are evolved (endothermic peak, $148{ }^{\circ} \mathrm{C}$; weight loss, $21.0 \%$ against a calculated value of $20.2 \%$ ) to yield $\left[\mathrm{Pd}(\mathrm{PyDT})_{2}\right]$ as degra- 
Table 2

Thermal data for the complexes

\begin{tabular}{|c|c|c|c|c|}
\hline \multirow[t]{2}{*}{ Compound } & \multirow[t]{2}{*}{ Decomposition interval $\left({ }^{\circ} \mathrm{C}\right)$} & \multicolumn{2}{|c|}{$T_{\mathrm{g}}$ weight loss $\%$} & \multirow[t]{2}{*}{ DTA Peak temperature $\left({ }^{\circ} \mathrm{C}\right)^{a}$} \\
\hline & & Experimental & Calculated & \\
\hline$\left[\mathrm{PdCl}_{2}(\mathrm{PyDTM})\right]$ & $\begin{array}{l}150-200 \\
280-830\end{array}$ & $\begin{array}{l}14.8 \\
52.6\end{array}$ & $\begin{array}{l}14.9\left(-\mathrm{CH}_{3} \mathrm{Cl}\right) \\
53.7 \text { (to } \mathrm{Pd})\end{array}$ & $\begin{array}{l}189 \text { endo } \\
384 \text { exo, } 823 \text { endo }\end{array}$ \\
\hline$\left[\mathrm{PdCl}_{2}(\mathrm{PyDTM})_{2}\right]$ & $\begin{array}{l}130-200 \\
280-830\end{array}$ & $\begin{array}{l}21.0 \\
57.8\end{array}$ & $\begin{array}{l}20.2\left(-2 \mathrm{CH}_{3} \mathrm{Cl}\right) \\
58.5(\text { to } \mathrm{Pd})\end{array}$ & $\begin{array}{l}148 \text { endo } \\
406 \text { exo, } 818 \text { endo }\end{array}$ \\
\hline$\left[\mathrm{Pd}(\mathrm{PyDT})_{2}\right]$ & $290-825$ & 72.9 & 73.3 (to $\mathrm{Pd}$ ) & 410 exo, 812 endo \\
\hline $\mathrm{NMe}_{4}\left[\mathrm{PdCl}_{2}(\mathrm{PyDT})\right]$ & $\begin{array}{l}25-260 \\
260-830\end{array}$ & $\begin{array}{l}- \\
72.9\end{array}$ & 73.2 (to Pd) & $\begin{array}{l}195 \text { endo } \mathrm{m} \\
287 \text { endo, } 395 \text { exo, } 822 \text { endo }\end{array}$ \\
\hline $\mathrm{NBu}_{4}\left[\mathrm{PdCl}_{2}(\mathrm{PyDT})\right]$ & $\begin{array}{l}25-190 \\
190-830\end{array}$ & $-\overline{81.4}$ & $\overline{8} 1.2$ (to $\mathrm{Pd})$ & $\begin{array}{l}102 \text { endo } \mathrm{m} \\
242 \text { endo, } 390 \text { exo, } 813 \text { endo }\end{array}$ \\
\hline [PdCl(PyDT)(PyDTM)] & $\begin{array}{l}150-200 \\
300-830\end{array}$ & $\begin{array}{l}11.5 \\
65.0\end{array}$ & $\begin{array}{l}11.2\left(-\mathrm{CH}_{3} \mathrm{Cl}\right) \\
65.1 \text { (to } \mathrm{Pd})\end{array}$ & $\begin{array}{l}160 \text { endo } \\
378 \text { endo, } 409 \text { exo, } 823 \text { endo }\end{array}$ \\
\hline [PdCl(DMDT)(PyDTM)] & $\begin{array}{l}135-175 \\
250-830\end{array}$ & $\begin{array}{l}11.7 \\
62.6\end{array}$ & $\begin{array}{l}11.9\left(-\mathrm{CH}_{3} \mathrm{Cl}\right) \\
63.0 \text { (to } \mathrm{Pd})\end{array}$ & $\begin{array}{l}139 \text { endo } \\
304 \text { endo, } 390 \text { exo, } 819 \text { endo }\end{array}$ \\
\hline$[\mathrm{PdCl}(\mathrm{ESDT})(\mathrm{PyDTM})]$ & $\begin{array}{l}130-200 \\
200-830\end{array}$ & $\begin{array}{l}11.0 \\
67.4\end{array}$ & $\begin{array}{l}10.2\left(-\mathrm{CH}_{3} \mathrm{Cl}\right) \\
68.3 \text { (to } \mathrm{Pd})\end{array}$ & $\begin{array}{l}\text { b } \\
377 \text { exo, } 394 \text { exo, } 812 \text { endo }\end{array}$ \\
\hline$[\mathrm{Pd}(\mathrm{DMDT})(\mathrm{PyDT})]$ & $280-830$ & 71.4 & 71.5 (to $\mathrm{Pd})$ & 376 exo, 402 exo, 822 endo \\
\hline$[\mathrm{Pd}(\mathrm{ESDT})(\mathrm{PyDT})]$ & $230-830$ & 75.4 & 76.1 (to Pd) & 375 exo, 400 exo, 823 endo \\
\hline [PdCl(PyDT)(DMSO)] & $\begin{array}{l}125-175 \\
280-830\end{array}$ & $\begin{array}{l}21.8 \\
48.7\end{array}$ & $\begin{array}{l}21.3 \text { (-DMSO) } \\
49.6 \text { (to } \mathrm{Pd})\end{array}$ & $\begin{array}{l}169 \text { endo } \\
391 \text { exo, } 822 \text { endo }\end{array}$ \\
\hline
\end{tabular}

a exo, exotherm; endo, endotherm; m, melting.

b The DTA curve is meaningless below $350^{\circ} \mathrm{C}$.

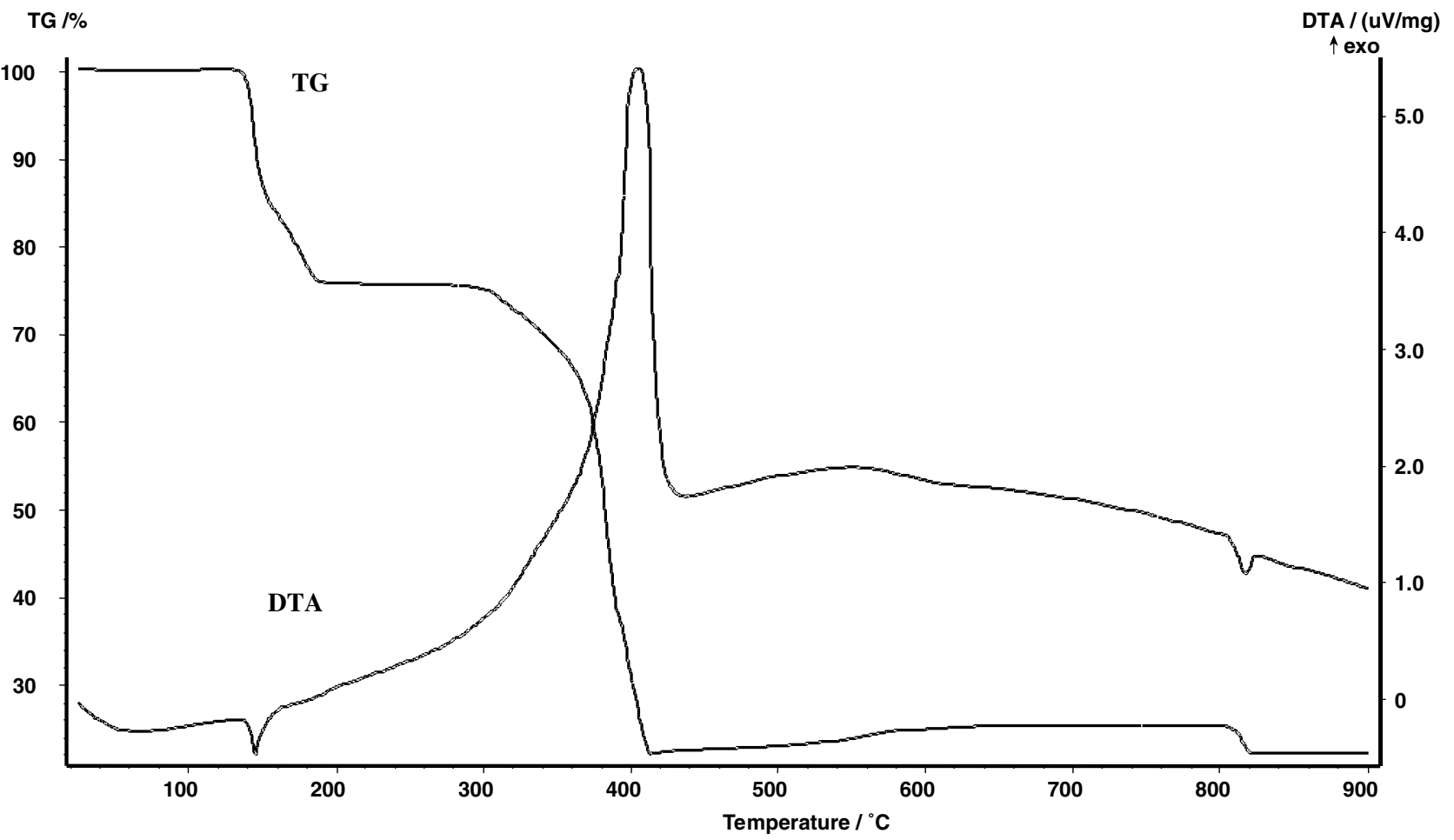

Fig. 2. Thermograms of $\left[\mathrm{PdCl}_{2}(\mathrm{PyDTM})_{2}\right]$

dation intermediate, which is stable up to $280^{\circ} \mathrm{C}$. Sample pyrolysis to palladium occurs in the $280-400{ }^{\circ} \mathrm{C}$ interval, with a total weight loss of $78.8 \%$ (calculated value $78.7 \%$ ).
The $\left[\mathrm{Pd}(\mathrm{PyDT})_{2}\right]$ complex can be easily prepared by reaction of $\mathrm{K}_{2}\left[\mathrm{PdCl}_{4}\right]$ and $\mathrm{NH}_{4} \mathrm{PyDT}$ in water (molar ratio 1:2). The fact that the infrared spectra of the yellow 
product obtained in this way are identical to those of samples obtained by heating up to $200^{\circ} \mathrm{C}$ of the parent dithioester complex allows to exclude the formation of sulfur bridges of different nature in the thermal degradation process. As shown in Fig. 2, methyl chloride release seems to occur in two successive, partly superimposed, steps. Such a trend suggests the initial release of one of the methyl chloride molecule to form the mixed dithiocarbamato/ dithioester species [PdCl- (PyDT)(PyDTM)] as a first intermediate.

The position of the $v(\mathrm{CN})$ absorption of ligand and complexes in the $1600-1450 \mathrm{~cm}^{-1}$ infrared region allows to identify the nature of examined species (Table 1). The $v(\mathrm{CN})$ band, observed at $1464 \mathrm{~cm}^{-1}$ for PyDTM, shifts to higher energy on coordination, owing to the increased double bond character in the $\mathrm{CN}$ group, caused by electron delocalization toward the metal center. The related absorption is observed at $1583 \mathrm{~cm}^{-1}$ for $\left[\mathrm{PdCl}_{2}(\mathrm{PyDTM})\right]$, with a shift of $119 \mathrm{~cm}^{-1}$ with respect of PyDTM, whereas the corresponding band for $\left[\mathrm{PdCl}_{2}(\mathrm{PyDTM})_{2}\right]$ falls at $1495 \mathrm{~cm}^{-1}\left(\Delta v=31 \mathrm{~cm}^{-1}\right)$. In the square planar $\left[\mathrm{PdCl}_{2}\right.$ (dithioester)] complexes, the metal coordinates both sulfur atoms of the ligand, the chelated configuration leading to reinforcement of the $\mathrm{CN}$ bond. As for $\left[\mathrm{PdCl}_{2}(\mathrm{PyDTM})\right]$, large $v(\mathrm{CN})$ shifts with respect of the corresponding free ligand have been observed for $\left[\mathrm{PdCl}_{2}(\mathrm{ESDTM})\right]\left(\Delta v=100 \mathrm{~cm}^{-1}\right)$ and $\left[\mathrm{PdCl}_{2}(\mathrm{DMDTM})\right]\left(\Delta v=84 \mathrm{~cm}^{-1}\right)$. Moreover, the cis configuration of those species is confirmed by the presence of two $\mathrm{Pd}-\mathrm{Cl}$ absorptions in the far infrared region, observed for $\left[\mathrm{PdCl}_{2}(\mathrm{PyDTM})\right]$ at 316 and $289 \mathrm{~cm}^{-1}$ (Table 3), as for [ $\left.\mathrm{PdCl}_{2}(\mathrm{ESDTM})\right]\left(322\right.$ and $\left.296 \mathrm{~cm}^{-1}\right)$ and $\left[\mathrm{PdCl}_{2}(\mathrm{DMDTM})\right]\left(318\right.$ and $\left.296 \mathrm{~cm}^{-1}\right)$. If the $\Delta v$ values of the $\mathrm{CN}$ absorptions can be correlated to the ligand coordination ability, it can be deduced that the PyDTM is the strongest donor in the series, the trend following the order PyDTM $>$ ESDTM $>$ DMDTM. In the
$\left[\mathrm{PdCl}_{2}(\text { dithioester })_{2}\right]$ complexes, the ligand molecules act as monodentate through the thiocarbonyl sulfur atom. The trans geometry of the molecule is supported by the single $\mathrm{Pd}-\mathrm{Cl}$ band, observed at $327 \mathrm{~cm}^{-1}$ in $\left[\mathrm{PdCl}_{2}(\mathrm{PyDTM})_{2}\right]$, whereas the $v(\mathrm{CN})$ shift with respect to PyDTM $\left(\Delta v=31 \mathrm{~cm}^{-1}\right)$ suggests that the monodentate dithioester is a weak S-donor, as for $\left[\mathrm{PdCl}_{2^{-}}\right.$ $\left.(\mathrm{ESDTM})_{2}\right] \quad\left(\Delta v=28 \mathrm{~cm}^{-1}\right)$ and $\left[\mathrm{PdCl}_{2}(\mathrm{DMDTM})_{2}\right]$ $\left(\Delta v=22 \mathrm{~cm}^{-1}\right)$. This fact explains the low stability of the 1:2 adducts in solution. In fact, those species tend to release one of the ligand molecules to form the parent $\left[\mathrm{PdCl}_{2}\right.$ (dithioester)] adduct, which can undergo $S$ demethylation to form $\left[\mathrm{PdCl}(\text { dithiocarbamate) }]_{n}\right.$, and, in the presence of the free ligand, the mixed $[\mathrm{PdCl}$ (dithiocarbamate)(dithioester)] complex, the main final product depending on time and sample solubility.

Although we do not dispose of experimental data which could clarify the $[\mathrm{PdCl}(\mathrm{PyDT})]_{n}$ nature, the complex consists probably of a polymeric arrangement of PdCl(PyDT) units, held by sulfur bridges. The crystal structure of the $[\mathrm{PdCl}(\text { mercaptonicotinic acid })]_{n}$ analogue showed that this compound is a trimer formed by $\mathrm{PdCl}$ (mercaptonicotinic acid) units in which the ion is chelated to palladium through the $\mathrm{N}$ and $\mathrm{S}$ atoms, the latter being at the same time bound to a nearby palladium atom [26]. The whole structure is then held by sulfur bridges, the chlorine atom being in terminal position. The $\mathrm{Pd}-\mathrm{Cl}$ absorption in $[\mathrm{PdCl}(\mathrm{PyDT})]_{n}$ was observed at $295 \mathrm{~cm}^{-1}$ (Table 3), below the corresponding band in $\left.\left[\mathrm{Pd}_{3} \mathrm{Cl}_{3} \text { (mercaptonicotinic acid }\right)_{3}\right]\left(322 \mathrm{~cm}^{-1}\right)$, whereas chlorine bridges between palladium atoms should absorb at lower wavelengths.

The $[\mathrm{PdCl}(\mathrm{PyDT})]_{n}$ intermediate can interact with neutral or ionic donors which are able to break the sulfur bridges. For example, in the presence of a large excess of dimethyl sulfoxide the [PdCl(PyDT)(DMSO)] complex is obtained, whereas the reaction with alkylam-

Table 3

Selected IR frequencies in the $500-150 \mathrm{~cm}^{-1}$ region $^{\mathrm{a}}$

\begin{tabular}{|c|c|c|c|c|c|c|c|c|c|c|c|c|}
\hline Compounds & $\begin{array}{l}\text { Freque } \\
\left(\mathrm{cm}^{-1}\right)\end{array}$ & & & & & & & & & & & \\
\hline PyDTM & & $453 \mathrm{~m}$ & $401 \mathrm{~s}$ & & & & $311 \mathrm{vw}$ & & $257 \mathrm{~s} \mathrm{br}$ & $239 \mathrm{sh}$ & $182 \mathrm{w}$ & \\
\hline$\left[\mathrm{PdCl}_{2}(\mathrm{PyDTM})\right]$ & & $436 \mathrm{w}$ & $402 \mathrm{w}$ & & $352 \mathrm{~m}$ & $336 \mathrm{~m}$ & $\underline{316 \mathrm{~s}}$ & $\underline{289 \mathrm{~m}}$ & & $202 \mathrm{w}$ & & $146 \mathrm{w}$ \\
\hline$[\mathrm{PdCl}(\mathrm{PyDT})]_{n}$ & & & $413 \mathrm{w}$ & $370 \mathrm{~ms}$ & $342 \mathrm{~m}$ & & $\underline{295 \mathrm{~s}}$ & & $261 \mathrm{w}$ & $194 \mathrm{~m}$ & & $155 \mathrm{vw}$ \\
\hline$\left[\mathrm{PdCl}_{2}(\mathrm{PyDTM})_{2}\right]$ & & $445 \mathrm{~ms}$ & $408 \mathrm{w}$ & & $345 \mathrm{~m}$ & & $\underline{327 \mathrm{~s}}$ & $301 \mathrm{vW}$ & $274 \mathrm{vw}$ & $216 \mathrm{w}$ & & \\
\hline$\left[\mathrm{Pd}(\mathrm{PyDT})_{2}\right]$ & & & $413 \mathrm{w}$ & & $345 \mathrm{~s}$ & $334 \mathrm{~s}$ & & & $246 \mathrm{vw}$ & & & \\
\hline $\mathrm{NMe}_{4}\left[\mathrm{PdCl}_{2}(\mathrm{PyDT})\right]$ & & $463 \mathrm{w}$ & $414 \mathrm{w}$ & $367 \mathrm{~m}$ & & $334 \mathrm{~m}$ & $\underline{292 s}$ & & $267 \mathrm{~m}$ & $201 \mathrm{w}$ & & \\
\hline $\mathrm{NBu}_{4}\left[\mathrm{PdCl}_{2}(\mathrm{PyDT})\right]$ & & $451 \mathrm{w}$ & $412 \mathrm{w}$ & $365 \mathrm{~m}$ & & $334 \mathrm{~m}$ & $\underline{306 \mathrm{~s}}$, & $\underline{280 \mathrm{~m}}$ & $206 \mathrm{w}$ & & & \\
\hline [PdCl(PyDT)(PyDTM)] & & $445 \mathrm{~m}$ & $407 \mathrm{w}$ & $358 \mathrm{~ms}$ & & $335 \mathrm{w}$ & $324 \mathrm{~m}$ & $\underline{295 \mathrm{~s}}$ & $266 \mathrm{w}$ & $224 \mathrm{w}$ & & \\
\hline$[\mathrm{PdCl}(\mathrm{DMDT})(\mathrm{PyDTM})]$ & & $445 \mathrm{~s}$ & $407 \mathrm{w}$ & $376 \mathrm{~s}$ & $350 \mathrm{~m}$ & & $320 \mathrm{w}$ & $\underline{303 \mathrm{~s}}$ & $268 \mathrm{w}$ & $237 \mathrm{w}$ & & \\
\hline [Pd(DMDT)(PyDT)] & & $441 \mathrm{w}$ & $415 \mathrm{w}$ & $375 \mathrm{w}$ & & $340 \mathrm{~m}$ & & & & & & \\
\hline [Pd(ESDT)(PyDT)] & $485 \mathrm{w}$ & & $415 \mathrm{w}$ & $378 \mathrm{w}$ & & $342 \mathrm{~m}$ & & & & & & \\
\hline$\left[\mathrm{Pd}(\mathrm{DMDT})_{2}\right]$ & & $441 \mathrm{w}$ & & & $359 \mathrm{~m}$ & $346 \mathrm{~m}$ & & & $268 \mathrm{w}$ & & & \\
\hline$\left[\mathrm{Pd}(\mathrm{ESDT})_{2}\right]$ & $486 \mathrm{w}$ & & $416 \mathrm{w}$ & & $359 \mathrm{~m}$ & & $322 \mathrm{w}$ & & & & & \\
\hline$[\mathrm{PdCl}(\mathrm{PyDT})(\mathrm{DMSO})]$ & & $451 \mathrm{vw}$ & $420 \mathrm{~m}$ & $382 \mathrm{~m}$ & $352 \mathrm{~m}$ & $335 \mathrm{w}$ & & $\underline{300 \mathrm{~m}}$ & & & & \\
\hline
\end{tabular}

${ }^{\text {a }} v(\mathrm{Pd}-\mathrm{Cl})$ underlined; w, weak; m, medium; s, strong; $\mathrm{b}$, broad; sh, shoulder; v, very. 
monium salts, as $\mathrm{NMe}_{4} \mathrm{Cl}$ and $\mathrm{NBu}_{4} \mathrm{Cl}$, allows to synthesize the ionic species $\mathrm{NR}_{4}\left[\mathrm{PdCl}_{2}(\mathrm{PyDT})\right]$. The $[\mathrm{PdCl}(\mathrm{PyDT})(\mathrm{DMSO})]$ spectrum contains the $v(\mathrm{CN})$ absorption at $1554 \mathrm{~cm}^{-1}$, whereas two strong bands are observed in the $900-1200 \mathrm{~cm}^{-1}$ region, which is diagnostic of the binding atom in coordinated dimethyl sulfoxide. The $v(\mathrm{SO})$ absorption, at $1125 \mathrm{~cm}^{-1}$ in the complex, is at high energy with respect to free dimethyl sulfoxide $\left(1055 \mathrm{~cm}^{-1}\right)$, as expected for a $\mathrm{S}$ bound molecule, whereas the one at $1022 \mathrm{~cm}^{-1}$ should originate from $\mathrm{CH}_{3}$ rock [27-29]. The fact that the $\mathrm{Pd}-\mathrm{Cl}$ band $\left(300 \mathrm{~cm}^{-1}\right)$ is very close to that of $[\mathrm{PdCl}(\mathrm{PyDT})]_{n}(295$ $\mathrm{cm}^{-1}$ ) supports the presence of terminal chloride ligands in the latter. As expected for cis chlorine atoms, the spectrum of $\mathrm{NBu}_{4}\left[\mathrm{PdCl}_{2}(\mathrm{PyDT})\right]$ shows two $\mathrm{Pd}-\mathrm{Cl}$ absorptions (306 and $280 \mathrm{~cm}^{-1}$ ), which overlap in $\mathrm{NMe}_{4}\left[\mathrm{PdCl}_{2}(\mathrm{PyDT})\right]$, yielding a broad band centered at $292 \mathrm{~cm}^{-1}$.

Dithiocarbamato intermediates, like [PdCl(DMDT) $]_{n}$ or $[\mathrm{PdCl}(\mathrm{ESDT})]_{n}$, react easily with dithioesters in chlorinated hydrocarbons with the formation of mixed species of the type $[\mathrm{PdCl}(\mathrm{ESDT})(\mathrm{L})](\mathrm{L}=\mathrm{ESDTM}$ or DMDTM) [24]. On the contrary, $[\mathrm{PdCl}(\mathrm{PyDT})]_{n}$ does not react with those dithioesters. The pink suspension is unchanged within one week, also if a large dithioester excess is used, whereas PyDTM reacts slowly in analoguos conditions to give the mixed [PdCl(PyDT) (PyDTM)] complex. Such a behaviour seems to confirm that PyDTM is a stronger S donor than ESDTM and DMDTM toward palladium. On the contrary, the mixed species $[\mathrm{PdCl}(\mathrm{ESDT})(\mathrm{PyDTM})]$ and $[\mathrm{PdCl}-$ (DMDT)(PyDTM)] are easily prepared by reaction of the parent intermediates with PyDTM in stoichiometric ratio. In the mixed complexes, the PyDTM molecule binds to palladium through the thiocarbonyl sulfur atom. Accordingly, the infrared spectra show two bands, assignable as $v(\mathrm{CN})$, the low energy one (ca. $1500 \mathrm{~cm}^{-1}$ ) belonging to monodentate dithioester. The band related to the dithiocarbamato moiety varies with the anion nature and is at $1561 \mathrm{~cm}^{-1}$ when the ion is DMDT, at $1520 \mathrm{~cm}^{-1}$ for ESDT and $1523 \mathrm{~cm}^{-1}$ for PyDT.

The first degradation process in the $[\mathrm{PdCl}$ (dithiocarbamato)(PyDTM)] thermograms is correlated to methyl chloride evolution to form the corresponding bis-dithiocarbamates. As shown in Fig. 3, [PdCl(PyDT) (PyDTM)] degradation starts at $150{ }^{\circ} \mathrm{C}$, the first step corresponding to $\mathrm{CH}_{3} \mathrm{Cl}$ release (weight loss of $11.5 \%$ against a calculated value of $11.2 \%$ ) to form $\left[\operatorname{Pd}(\operatorname{PyDT})_{2}\right]$, which is stable up to $300{ }^{\circ} \mathrm{C}$. Accordingly, the mixed species [PdCl(DMDT)(PyDTM)] and [PdCl(ESDT)(PyDTM)] transform, in the appropriate temperature range, into the asymmetrical dithiocarbamates $[\mathrm{Pd}(\mathrm{ESDT})(\mathrm{PyDT})]$ and $[\mathrm{Pd}(\mathrm{DMDT})(\mathrm{PyDT})]$. The symmetrical bis-dithiocarbamate $\left[\operatorname{Pd}(\mathrm{DMDT})_{2}\right]$ shows one $v(\mathrm{CN})$ absorption at $1548 \mathrm{~cm}^{-1}$, shifted to lower energy in the ESDT $\left(1517 \mathrm{~cm}^{-1}\right)$ and PyDT $\left(1511 \mathrm{~cm}^{-1}\right)$ analogues. The presence of different dithiocarbamato ions originates the two $v(\mathrm{CN})$ absorptions in $[\mathrm{Pd}(\mathrm{DMDT})(\mathrm{PyDT})]\left(1548\right.$ and $\left.1511 \mathrm{~cm}^{-1}\right)$, whereas one broad band is observed for [Pd(ESDT)(PyDT)] $\left(1514 \mathrm{~cm}^{-1}\right)$, due to overlap of the close absorptions of the two dithiocarbamato moieties. All complex spectra contain well resolved absorptions in the $400-300 \mathrm{~cm}^{-1}$ range, which are absent in free PyDTM (Table 3). Vibrations of Pd-S bond are usually found in this region, but it is hard to assign the observed absorptions to coordination modes of ionic or neutral ligands.

Owing to the barrier to rotation about the $\mathrm{CN}$ bond (ca. $63 \mathrm{~kJ} \mathrm{~mol}^{-1}$ ), the dialkyldithioester molecule is planar and the nitrogen substituents are magnetically nonequivalent [30-32]. For this reason, the proton NMR spectrum of DMDTM in deuterated chloroform contains two distinct singlets for the methyl groups bound to nitrogen (3.55 and $3.38 \mathrm{ppm}$ ), along with the $\mathrm{SCH}_{3}$ singlet at $2.64 \mathrm{ppm}$, palladium coordination causing a general downshift [29]. The PyDTM spectrum in the same solvent (Table 4) shows two signals for the methylene groups bound to nitrogen (3.88 and $3.60 \mathrm{ppm})$, originated from the different positions (syn or anti) with respect to the thiocarbonyl group in the planar molecule.

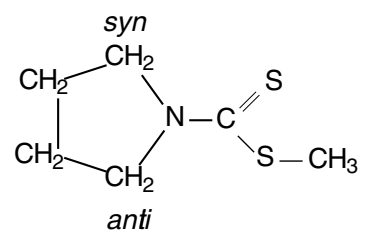

The signals at 2.04 and $1.93 \mathrm{ppm}$ belong to the chain $\left(\mathrm{CH}_{2}\right)_{2}$ protons, which are affected by the nearby $\mathrm{N}\left(\mathrm{CH}_{2}\right)_{2}$ methylene situation. The $\mathrm{SCH}_{3}$ singlet is at ca. $2.6 \mathrm{ppm}$ in the examined solvents (Table 4), whereas the methylene group resonances undergo an upfield shift in benzene, due to interaction with ring current. The ${ }^{13} \mathrm{C}$ NMR spectrum of PyDTM in $\mathrm{CDCl}_{3}$ contains two signals for either $\mathrm{N}\left(\mathrm{CH}_{2}\right)_{2}$ (54.6 and $50.2 \mathrm{ppm}$ ) or ring $\left(\mathrm{CH}_{2}\right)_{2}$ (25.8 and $24.0 \mathrm{ppm}$ ) groups, the $\mathrm{SCH}_{3}$ and $\mathrm{CS}_{2}$ resonances being at 19.1 and $193.3 \mathrm{ppm}$, respectively. The proton NMR spectrum of $\left[\mathrm{PdCl}_{2}(\mathrm{PyDTM})_{2}\right]$ in $\mathrm{CDCl}_{3}$ supports the low stability of the complex. As shown in Fig. 4, the spectrum, registered within a few minutes after sample dissolution, contains two series of signals, the more intense belonging to the 1:2 complex. Ligand coordination is inferred by the downfield shift of the $\mathrm{SCH}_{3}$ singlet (2.92 ppm), the $\mathrm{N}\left(\mathrm{CH}_{2}\right)_{2}$ resonances (4.60 and $3.65 \mathrm{ppm}$ ) being far apart, the separation (ca. $1 \mathrm{ppm}$ ) being larger than for PyDTM (ca. 0.3 ppm). The weak signals at $2.64 \mathrm{ppm}\left(\mathrm{SCH}_{3}\right)$ and 3.94 , 


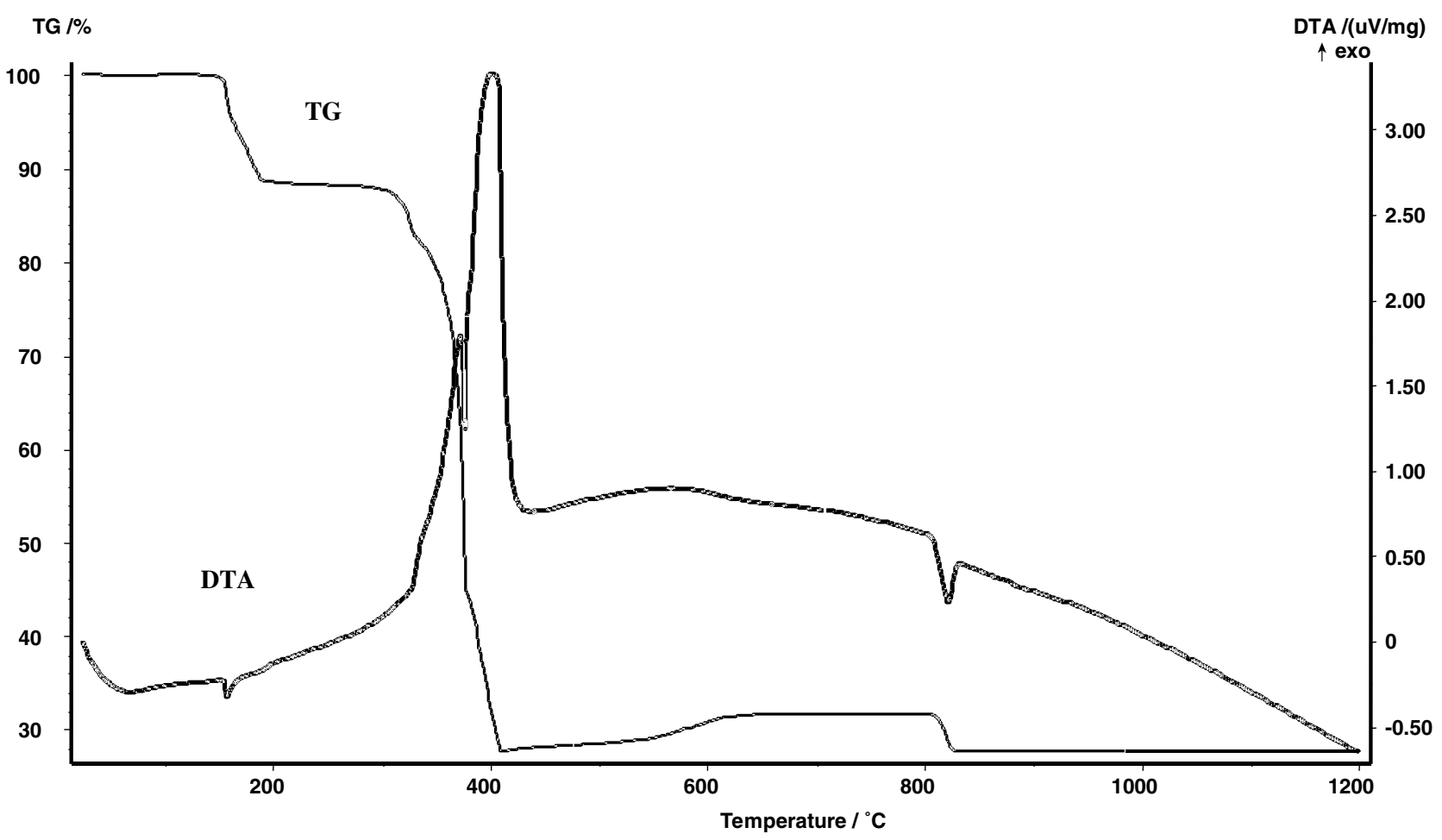

Fig. 3. Thermograms of $[\mathrm{PdCl}(\mathrm{PyDT})(\mathrm{PyDTM})]$.

Table 4

Proton NMR data (ppm; $T$, ca. $25^{\circ} \mathrm{C}$ )

\begin{tabular}{|c|c|c|c|c|c|}
\hline Compound & Solvent & $\mathrm{SCH}_{3}$ & $\mathrm{~N}\left(\mathrm{CH}_{2}\right)_{2}$ & $\left(\mathrm{CH}_{2}\right)_{2}$ & Other \\
\hline \multirow[t]{3}{*}{ PyDTM } & $\mathrm{CDCl}_{3}$ & 2.60 & $3.88,3.60$ & $2.04,1.93$ & \\
\hline & $\left(\mathrm{CD}_{3}\right)_{2} \mathrm{SO}$ & 2.54 & $3.76,3.60$ & $2.01,1.90$ & \\
\hline & $\mathrm{C}_{6} \mathrm{D}_{6}$ & 2.56 & $3.68,3.07$ & 1.08 & \\
\hline \multirow{3}{*}[\mathrm{PdCl}_{2}(\mathrm{PyDTM})]{} & $\left(\mathrm{CD}_{3}\right)_{2} \mathrm{SO}$ & $2.83^{\mathrm{a}}$ & $4.19^{\mathrm{a}}, 3.62^{\mathrm{a}}$ & $2.03^{\mathrm{a}}, 1.90^{\mathrm{a}}$ & \\
\hline & & $2.58^{\mathrm{b}}$ & $3.78^{\mathrm{b}}, 3.62^{\mathrm{b}}$ & $2.03^{\mathrm{b}}, 1.90^{\mathrm{b}}$ & \\
\hline & & & $3.62^{\mathrm{c}}$ & $2.03^{\mathrm{c}}, 1.90^{\mathrm{c}}$ & \\
\hline$[\mathrm{PdCl}(\mathrm{PyDT})]_{n}$ & $\left(\mathrm{CD}_{3}\right)_{2} \mathrm{SO}$ & & 3.66 & 1.97 & \\
\hline \multirow[t]{4}{*}[\mathrm{PdCl}_{2}(\mathrm{PyDTM})_{2}]{} & $\mathrm{CDCl}_{3}$ & $2.92^{\mathrm{a}}$ & $4.60^{\mathrm{a}}, 3.65^{\mathrm{a}}$ & $2.13^{\mathrm{a}}, 2.11^{\mathrm{a}}$ & \\
\hline & & $2.64^{\mathrm{b}}$ & $3.94^{\mathrm{b}}, 3.65^{\mathrm{b}}$ & $2.00^{\mathrm{b}}, 1.98^{\mathrm{b}}$ & \\
\hline & $\left(\mathrm{CD}_{3}\right)_{2} \mathrm{SO}$ & $2.83^{\mathrm{a}}$ & $4.19^{\mathrm{a}}, 3.62^{\mathrm{a}}$ & $2.02^{\mathrm{a}}, 1.92^{\mathrm{a}}$ & \\
\hline & & $2.55^{\mathrm{b}}$ & $3.76^{\mathrm{b}}, 3.61^{\mathrm{b}}$ & $2.02^{\mathrm{b}}, 1.92^{\mathrm{b}}$ & \\
\hline$\left[\mathrm{Pd}(\mathrm{PyDT})_{2}\right]$ & $\left(\mathrm{CD}_{3}\right)_{2} \mathrm{SO}$ & & 3.60 & 1.95 & \\
\hline $\mathrm{NMe}_{4}\left[\mathrm{PdCl}_{2}(\mathrm{PyDT})\right]$ & $\left(\mathrm{CD}_{3}\right)_{2} \mathrm{SO}$ & & 3.66 & 1.98 & $\mathrm{~N}\left(\mathrm{CH}_{3}\right)_{4}: 3.10$ \\
\hline $\mathrm{NBu}_{4}\left[\mathrm{PdCl}_{2}(\mathrm{PyDT})\right]$ & $\mathrm{CDCl}_{3}$ & & 3.60 & 2. 00 & $\mathrm{~N}\left[\left(\mathrm{CH}_{2}\right)_{3} \mathrm{CH}_{3}\right]_{4}: 3.46,1.78,1.51,1.02$ \\
\hline \multirow[t]{2}{*}[\mathrm{PdCl}(\mathrm{PyDT})(\mathrm{PyDTM})]{} & $\mathrm{CDCl}_{3}$ & 2.93 & $4.58,3.74$ & $2.20-2.00$ & \\
\hline & & $2.66^{\mathrm{b}}$ & $3.95^{\mathrm{b}}, 3.66^{\mathrm{b}}$ & $2.20-2.00$ & \\
\hline \multirow[t]{2}{*}{ [PdCl(DMDT)(PyDTM)] } & $\mathrm{CDCl}_{3}$ & 2.92 & $4.56,3.74$ & $2.15,2.12$ & DMDT: $3.23,3.22,\left(\mathrm{~N}\left(\mathrm{CH}_{3}\right)_{2}\right)$ \\
\hline & & $2.66^{\mathrm{b}}$ & $3.95^{\mathrm{b}}, 3.65^{\mathrm{b}}$ & $2.15^{\mathrm{b}}, 2.12^{\mathrm{b}}$ & \\
\hline$[\mathrm{PdCl}(\mathrm{ESDT})(\mathrm{PyDTM})]$ & $\mathrm{CDCl}_{3}$ & 2.93 & $4.56,3.75$ & $2.16,2.14$ & ESDT: $3.30, \mathrm{~N}\left(\mathrm{CH}_{3}\right) ; 4.36, \mathrm{~N}\left(\mathrm{CH}_{2}\right) ; 4.26,1.31$, OEt \\
\hline$[\mathrm{Pd}(\mathrm{DMDT})(\mathrm{PyDT})]$ & $\left(\mathrm{CD}_{3}\right)_{2} \mathrm{SO}$ & & 3.61 & 1.95 & DMDT: $3.23, \mathrm{~N}\left(\mathrm{CH}_{3}\right)_{2}$ \\
\hline \multirow[t]{2}{*}[\mathrm{Pd}(\mathrm{ESDT})(\mathrm{PyDT})]{} & $\mathrm{CDCl}_{3}$ & & 3.71 & 2.03 & ESDT: $3.34, \mathrm{~N}\left(\mathrm{CH}_{3}\right) ; 4.44, \mathrm{~N}\left(\mathrm{CH}_{2}\right) ; 4.25,1.30, \mathrm{OEt}$ \\
\hline & $\left(\mathrm{CD}_{3}\right)_{2} \mathrm{SO}$ & & 3.62 & 1.96 & ESDT: $3.30, \mathrm{~N}\left(\mathrm{CH}_{3}\right) ; 4.56, \mathrm{~N}\left(\mathrm{CH}_{2}\right) ; 4.16,1.21, \mathrm{OEt}$ \\
\hline$\left[\mathrm{Pd}(\mathrm{PyDT})_{2}\right]$ & $\left(\mathrm{CD}_{3}\right)_{2} \mathrm{SO}$ & & 3.60 & 1.95 & \\
\hline$\left[\mathrm{Pd}(\mathrm{DMDT})_{2}\right]$ & $\left(\mathrm{CD}_{3}\right)_{2} \mathrm{SO}$ & & & & DMDT: $3.23, \mathrm{~N}\left(\mathrm{CH}_{3}\right)_{2}$ \\
\hline \multirow[t]{2}{*}[\mathrm{Pd}(\mathrm{ESDT})_{2}]{} & $\mathrm{CDCl}_{3}$ & & & & ESDT: $3.34, \mathrm{~N}\left(\mathrm{CH}_{3}\right) ; 4.44, \mathrm{~N}\left(\mathrm{CH}_{2}\right) ; 4.25,1.30, \mathrm{OEt}$ \\
\hline & $\left(\mathrm{CD}_{3}\right)_{2} \mathrm{SO}$ & & & & ESDT: $3.27, \mathrm{~N}\left(\mathrm{CH}_{3}\right) ; 4.57, \mathrm{~N}\left(\mathrm{CH}_{2}\right) ; 4.16,1.21, \mathrm{OEt}$ \\
\hline
\end{tabular}

a The signal belongs to monodentate PyDTM.

b The signal belongs to free PyDTM.

c The signal belongs to [PdCl(PyDTM)(DMSO)]. 
$3.65 \mathrm{ppm}\left(\mathrm{N}\left(\mathrm{CH}_{2}\right)_{2}\right)$ are originated by incipient PyDTM release to form $\left[\mathrm{PdCl}_{2}(\mathrm{PyDTM})\right]$. Complex dissociation increases with time, with progressive separation of the insoluble 1:1 complex, the 1:2 complex being held in solution by the free ligand excess, in an heterogeneous equilibrium situation like

$\left[\mathrm{PdCl}_{2}(\mathrm{PyDTM})_{2}\right] \leftrightarrows\left[\mathrm{PdCl}_{2}(\mathrm{PyDTM})\right](\mathrm{s})+\mathrm{PyDTM}$

In the final spectrum, the amount of coordinated and free PyDTM can be estimated by the well evident $\mathrm{SCH}_{3}$ signals (at 2.92 and $2.64 \mathrm{ppm}$, respectively). The downfield $\mathrm{N}\left(\mathrm{CH}_{2}\right)_{2}$ signal $(4.60 \mathrm{ppm})$ belongs to one of the methylene groups bound to nitrogen in the 1:2 complex, the parallel signal in free PyDTM being at $3.94 \mathrm{ppm}$. The resonance of the second methylene group in both coordinated and free PyDTM overlap in the signal at $3.65 \mathrm{ppm}$.

The pink $[\mathrm{PdCl}(\mathrm{PyDT})]_{n}$ polymer dissolves in DMSO yielding the yellow [PdCl(PyDT)(DMSO)] complex. Owing to the anion symmetry, the proton spectrum is very simple, the two signals at 3.66 and $1.97 \mathrm{ppm}$ being assigned to $\mathrm{N}\left(\mathrm{CH}_{2}\right)_{2}$ and $\left(\mathrm{CH}_{2}\right)_{2}$ protons, respectively. The complex $\left[\mathrm{PdCl}_{2}(\mathrm{PyDTM})\right]$ undergoes massive decomposition in the same solvent, the initial interaction with DMSO causing the chelate opening to form the $\left[\mathrm{PdCl}_{2}(\mathrm{PyDTM})(\mathrm{DMSO})\right]$ species, which contains monodentate dithioester. Further interaction with solvent causes partial PyDTM release to form $\left[\mathrm{PdCl}_{2}(\mathrm{DMSO})_{2}\right]$, along with partial $S$-demethylation to give $[\mathrm{PdCl}(\mathrm{PyDT})(\mathrm{DMSO})]$. Consequently, the spec-
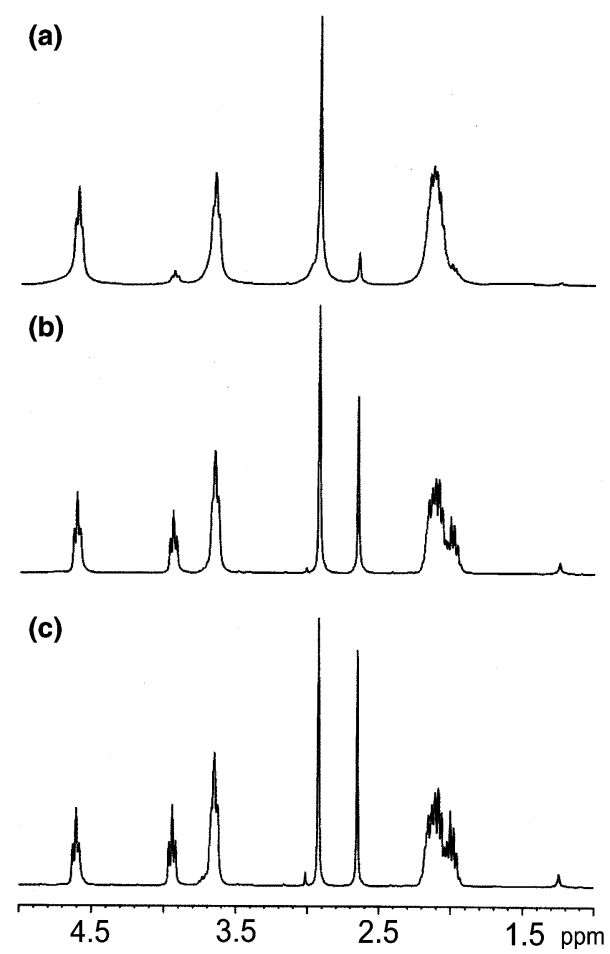

Fig. 4. Proton NMR spectrum of $\left[\mathrm{PdCl}_{2}(\mathrm{PyDTM})_{2}\right]$ in $\mathrm{CDCl}_{3}$ : (a) after 2 min from dissolution; (b) after two days; (c) after five days. trum contains broad signals, owing to superimposition of free PyDTM and DMSO complex resonances (Table 4). A similar degradation trend in DMSO is observed for $\left[\mathrm{PdCl}_{2}(\mathrm{PyDTM})_{2}\right]$, the main species being PyDTM and $[\mathrm{PdCl}(\mathrm{PyDTM})(\mathrm{DMSO})]$, with traces of demethylation.

The behaviour of the $[\mathrm{PdCl}$ (dithiocarbamato)(PyDTM)] complexes in $\mathrm{CDCl}_{3}$ depends on the nature of the dithiocarbamato ion. The spectrum of [PdCl(ESDT)(PyDTM)] contains well resolved signals of monodentate PyDTM, at $2.93 \mathrm{ppm}\left(\mathrm{SCH}_{3}\right)$ and 4.56 and $3.75 \mathrm{ppm}\left(\mathrm{N}\left(\mathrm{CH}_{3}\right)_{2}\right)$, the ESDT ion resonances showing the $\mathrm{N}\left(\mathrm{CH}_{3}\right)$ and $\mathrm{N}\left(\mathrm{CH}_{2}\right)$ signals at 3.30 and $4.36 \mathrm{ppm}$, respectively [13]. The main resonances in the $[\mathrm{PdCl}(\mathrm{DMDT})(\mathrm{PyDTM})]$ spectrum belong to the complex, very weak free PyDTM signals suggesting incipient dissociation. Ligand release is instead evident for $[\mathrm{PdCl}(\mathrm{PyDT})(\mathrm{PyDTM})]$, with progressive precipitation of $[\mathrm{PdCl}(\mathrm{PyDT})]_{n}$. The spectra of the asymmetrical dithiocarbamates contain the signals of the ions present in the molecule, which are coincident with those observed for the parent bis-dithiocarbamates.

\section{Acknowledgments}

We thank Annamaria Moresco for experimental help and technical assistance. One of us (Diego Montagner) thanks the "Consorzio Interuniversitario di Ricerca in Chimica dei Metalli nei Sistemi Biologici" for a grant.

\section{References}

[1] B. Desoize, C. Madoulet, Crit. Rev. Oncol./Hematol. 42 (2002) 317.

[2] E. Wong, C.M. Giandomenico, Chem. Rev. 99 (1999) 2451.

[3] Z. Guo, P.J. Sadler, Adv. Inorg. Chem. 49 (2000) 183.

[4] B. Lippert, Coord. Chem. Rev. 182 (1999) 263.

[5] K. Lemma, S.K.C. Elmroth, L.I. Elding, J. Chem. Soc., Dalton Trans. (2002) 1281.

[6] J. Landi, M.P. Hacker, N. Farrel, Inorg. Chim. Acta 202 (1992) 79.

[7] E.C.H. Ling, G.W. Allen, T.W. Hambley, J. Chem. Soc., Dalton Trans. (1993) 3705.

[8] A. Pasini, G. D'Alfonso, C. Manzotti, M. Moret, et al., Inorg. Chem. 33 (1994) 4140

[9] R. Mital, N. Jain, T.S. Srivastava, Inorg. Chim. Acta 166 (1989) 135.

[10] G. Faraglia, L. Sindellari, V. Cerchi, A. Furlani, A. Papaioannou, V. Scarcia, Transit. Met. Chem. 18 (1993) 45.

[11] A. Furlani, V. Scarcia, G. Faraglia, L. Sindellari, L. Trincia, M. Nicolini, Eur. J. Med. Chem. 21 (1986) 261.

[12] G. Faraglia, L. Sindellari, S. Sitran, Thermochim. Acta 161 (1990) 63.

[13] G. Faraglia, D. Longo, V. Cherchi, S. Sitran, Polyhedron 14 (1995) 1905.

[14] D. Fregona, S. Tenconi, G. Faraglia, S. Sitran, Polyhedron 16 (1997) 3795. 
[15] G. Faraglia, D. Fregona, S. Sitran, L. Giovagnini, C. Marzano, F. Baccichetti, U. Casellato, R. Graziani, J. Inorg. Biochem. 83 (2001) 31 .

[16] C. Marzano, D. Fregona, F. Baccichetti, A. Trevisan, L. Giovagnini, F. Bordin, Chem.-Biol. Interact. 140 (2002) 215.

[17] C. Marzano, A. Trevisan, L. Giovagnini, D. Fregona, Toxicol. In Vitro 16 (2002) 413.

[18] A. Trevisan, C. Marzano, P. Cristofori, M. Borella Venturini, L. Giovagnini, D. Fregona, Arch. Toxicol. 76 (2002) 262.

[19] S. Cuzzocrea, P.K. Chatterjee, E. Mazzon, L. Dugo, et al., Brit. J. Pharmacol. 135 (2002) 496.

[20] S.H. Kim, S.I. Hans, S.Y. Oh, H.Y. Chung, et al., Biochem. Biophys. Res. Commun. 281 (2001) 367.

[21] E. Gaudernak, J. Speipelt, A. Triendl, A. Grassauer, et al., J. Virol. 76 (2002) 6004.

[22] S.R. Thomas, H. Salahifar, R. Mashima, N.H. Hunt, et al., J. Immunol. 166 (2001) 6332.
[23] R. Bruck, H. Aeed, R. Schey, Z. Matas, et al., J. Hepatol. 36 (2002) 370.

[24] S. Furuta, F. Ortiz, X.Z. Sun, H.H. Wu, et al., Biochem. J. 365 (Part 3) (2002) 639.

[25] G. Faraglia, L. Sindellari, S. Sitran, Transit. Met. Chem. 19 (1994) 248.

[26] S. Marchal, V. Moreno, G. Aullón, S. Alvarez, M. Quirós, M. Font.Bardia, X. Solans, Polyhedron 18 (1999) 3675.

[27] J.A. Davies, Adv. Inorg. Chem. Radiochem. 24 (1981) 115.

[28] G.A. Heath, A.J. Lindsay, T.A. Stephenson, J. Chem. Soc., Dalton Trans. (1982) 2429.

[29] G. Faraglia, S. Sitran, Inorg. Chim. Acta 176 (1990) 67.

[30] A.E. Lemire, J.C. Thompson, Can. J. Chem. 48 (1970) 824.

[31] A.E. Lemire, J.C. Thompson, J. Am. Chem. Soc. 93 (1971) 1163.

[32] C.H. Yoder, A. Komoriya, J.E. Kochanowsky, F.H. Suydam, J. Am. Chem. Soc. 93 (1971) 6515. 